\title{
The Effectiveness of the Career Guidance Module to Improve Career Maturity for Children with Special Needs in Inclusive Vocational High Schools
}

\author{
Laras Ambar Wati ${ }^{1 *}$, Gunarhadi ${ }^{2}$, Asrowi $^{3}$ \\ 1,2,3 Post Graduate of Special Education Departement, Sebelas Maret University, Surakarta, Indonesia \\ *Corresponding author: larasambar58@gmail.com
}

\begin{abstract}
This research is conducted based on children with special needs in Vocational High Schools, which has no good career maturity. Moreover, there are no basic career materials for children with special needs in the Vocational High Schools in Surakarta. Therefore, this research aims to develop the teaching materials in the form of a career guidance module to improve career maturity for children with special needs in the Inclusive Vocational High Schools in Surakarta. The method used in this research is Research and Development $(\mathrm{RnD})$ research. The data analysis technique used in this research is the categorization formula. The research finding showed that the developed module had been appropriately stated to be used according to the test result by both experts and practitioners' validators. Meanwhile, the effectiveness test result showed a score improvement of children with special needs compared to the previous pre-tests and post-tests.
\end{abstract}

Keywords: Effectiveness Module, Career Maturity, Children With Special Needs

$\begin{array}{ll}\text { History: } & \text { Publisher: Undiksha Press } \\ \text { Received : 2 January } 2021 & \text { Licensed: This work is licensed under } \\ \text { Revised } \quad \text { : } 15 \text { February } 2021 & \text { a Creative Commons Attribution 3.0 License } \\ \text { Accepted : 26cMarch } 2021 & \\ \text { Published : 25 April } 2021 & \end{array}$

\section{Introduction}

A career is one of the essential things for an individual. Individuals will prepare for their careers from school to enter the industrial world. One of the essential aspects to support career success is career maturity. Every individual who chooses a particular career decision requires career maturity to be prepared early in school. School is where students can develop their talents and potential interests (Liu et al., 2017). Career maturity is an individual who has planned for the future and has the readiness to make career decisions that are appropriate to their age and stage of development (Munawir et al., 2018; Riyadi, 2017). Career maturity is a significant point in career development that will affect students' future lives (Lestari \& Tentama, 2020; Polignano, 2019). Individuals who have high career maturity have a greater chance of achieving career success in the future compared to individuals who have low career maturity (Heiriyah \& Haryadi, 2019; Risqiyain \& Purwanta, 2019).

Adolescence is when individuals begin to enter a transitional period from the education phase to the industrial world or the advanced education level. Preparing students for the transition period is an essential role that schools should do (Carter et al., 2020; Johnson et al., 2020; Lau et al., 2019). Career development for an individual aged 16-24 belongs to the exploration stage (Munawir et al., 2018). The exploration process occurs in vocational students. Students begin to identify career options and explore career goals but have not yet made binding decisions. In this exploration stage, students begin to find 
information about the industrial world, make career decisions, and focus on the sector of interest to prepare for the industrial world (Risqiyain \& Purwanta, 2019).

In this exploration stage, many students do not have mature career planning and career goals. Students who do not have good career maturity will face problems in choosing careers and making career decisions (Risqiyain \& Purwanta, 2019). This statement is in line with the data from the Central Bureau of Statistics (BPS), which explained that the Open Unemployment Rate (TPT) in May 2020). The highest unemployment percentage is Vocational school graduates (8.49), High school graduates (6.77\%), Diploma graduates $(6.76 \%)$, university graduates $(5.73 \%)$, Junior high school graduates $(5.02 \%)$, and the lowest Open Unemployment is Elementary school graduates with the percentage is 2.64\%. From the data, it can be concluded that Vocational school graduates are the highest open unemployment percentage. Therefore, vocational school graduates should be prepared to be ready to work after their graduation.

Unemployment of Vocational school graduates does not only occur to non-special needs students, but also students with special needs are more likely to experience unemployment and difficulties in finding work and do not get equality (Dispenza, 2019) and requires more attention in developing their career (Heiriyah \& Haryadi, 2019). The problem faced by children with special needs is the high unemployment level since they do not get equal rights by the employer, such as lower wages and job dissatisfaction. Moreover, they do not have job skills and lack access to higher education (Bonaccio, 2019; Dispenza, 2019; Lombardi et al., 2018). The obstacles of children with special needs in finding jobs indicate that children with special needs have not gotten equality. Meanwhile, children's right with special needs in obtaining job have been regulated in the Law of the Republic of Indonesia Number 8 of 2016 regarding Persons with Disabilities in article 8 (a), which is to have the rights to get jobs organized by the Government, Local Government or the private sector without any discrimination. Children with special needs have the rights to get a job, get accommodation and equivalent wages to individuals with no special needs.

Children with special needs have issues in the transition period from the results of interviews with guidance and counselling teachers of Surakarta Inclusive Vocational School explained that the low career maturity of students with special needs is because there is no particular schedule for career guidance session. Guidance is only conducted in the Guidance room with no specific material difference between students in general and students with special needs. Education for children with special needs at Vocational high school is supposed to be the inclusive education model (Qvortrup \& Qvortrup, 2018). Career guidance programs in inclusive schools for children with special needs should focus on encouraging the career decision of children with special needs and providing opportunities for skills development, job training and providing information about jobs to help children with special needs in achieving their potential (Carter et al., 2020; Chun et al., 2016; Majoko, 2019).

Previous research conducted by Johnson et al. (2020) stated that students with special needs experience more challenges and limitations in preparing for work than other students. Career maturity services provide students with information on steps for planning and making career decisions. However, lack of understanding of careers makes students unprepared or immature in determining future careers (Kosine et al., 2008). In addition, less optimal career guidance services in schools are also becoming the factor of the low career maturity of students with special needs. Therefore, in implementing career guidance, media or teaching materials are needed. Related research from Risqiyain \& Purwanta (2019) showed that the use of media in interactive multimedia for adequate career information is proven to improve the career maturity of vocational students. The alternative used by researchers to help students in their career maturity is by using a module. 
Learning using module helps students to achieve independence. According to Trianasari \& Purwanta (2019), students can learn more directed and systematically using the module. The selection of a guidance module as teaching material is in line with Talib et al. (2015), which showed that a career guidance module could significantly improve career planning skills and career maturity. Relevant research shows that applying a career guidance module can improve adolescent career planning (Wijaya et al., 2020). The use of the career guidance module in learning by previous researchers (Periyanto \& Setyowati, 2017; Alfriansyah \& Widarto, 2018) proved that it could provide effective support in career programs with different samples.

Based on the explanations above, career maturity can be improved using career guidance module media as teaching materials. The development of this teaching material is expected to assist counselling teachers in carrying out guidance to students with special needs to learn independently in an unlimited amount of time and improve student career maturity to choose a career in the future. Therefore, this study aims to develop teaching materials in career guidance modules to increase students' career maturity with disabilities in Surakarta Inclusion Vocational School.

\section{Materials and Methods}

This research was conducted in three Inclusive Vocational High Schools (SMK) in Surakarta, consisting of SMK N 4, SMK N 8, and SMK N 9 in July-December 2020. The method used in this research is Development research $(\mathrm{RnD})$. This research used 3 steps regarding the theory of Borg and Gall, which has been modified by Sukmadinata (2012), covering (1) introduction study, (2) development model, and (3) testing model. The first stage is an introductory study to obtain a career maturity level before being given a module. The data collection used is a career maturity instrument from Super theory modified by Alvarez (2008). The second stage is developing a learning model to provide a career guidance module for children with special needs consisting of 5 aspects of career maturity based on Super theory (Alvarez, 2008). The third stage, the test model design module of the worthiness test, consists of expert testing (expert validators) and practitioner tests.

Expert validation test consists of 4 experts, covering experts of guidance and counselling, experts in special education, experts of languages, and graphics experts. In this worthiness test, the experts gave an assessment of the developed module and then the researcher revised stage 1 . In addition, to conduct the worthiness test by the experts, this research also conducted a practitioner test conducted by 11 guidance and counselling teachers. Finally, the researcher made the stage 2 revision based on the assessments and suggestions given by the practitioners. The final score will be re-analyzed use the scoring categorization criteria as shown in Table 1.

Table 1. Scoring Criteria

\begin{tabular}{cc}
\hline Category & Criteria \\
\hline High & $X>$ Hypothetic mean +1 SD Hypothetic \\
Moderate & (Hypothetic Mean -1 SD Hypothetic) $\leq \mathrm{X} \leq$ (Hypothetic Mean +1 SD \\
Low & Hypothetic) \\
\hline & (Saiffudin Azwar, 2012)
\end{tabular}




\section{Results and Discussion Results}

There are three stages of findings of the development research, are as follow:

\section{Introduction Study}

Career guidance module for students with special needs at Inclusive Vocational High School is developed based on needs analysis and actual conditions, including the career maturity level of students with special needs. The initial career maturity level is obtained through career maturity instruments that the experts have validated. The instrument was given to 30 students with special needs in the Inclusive Vocational School of Surakarta via Google form. Data of early-career maturity levels will be presented in Figure 1.

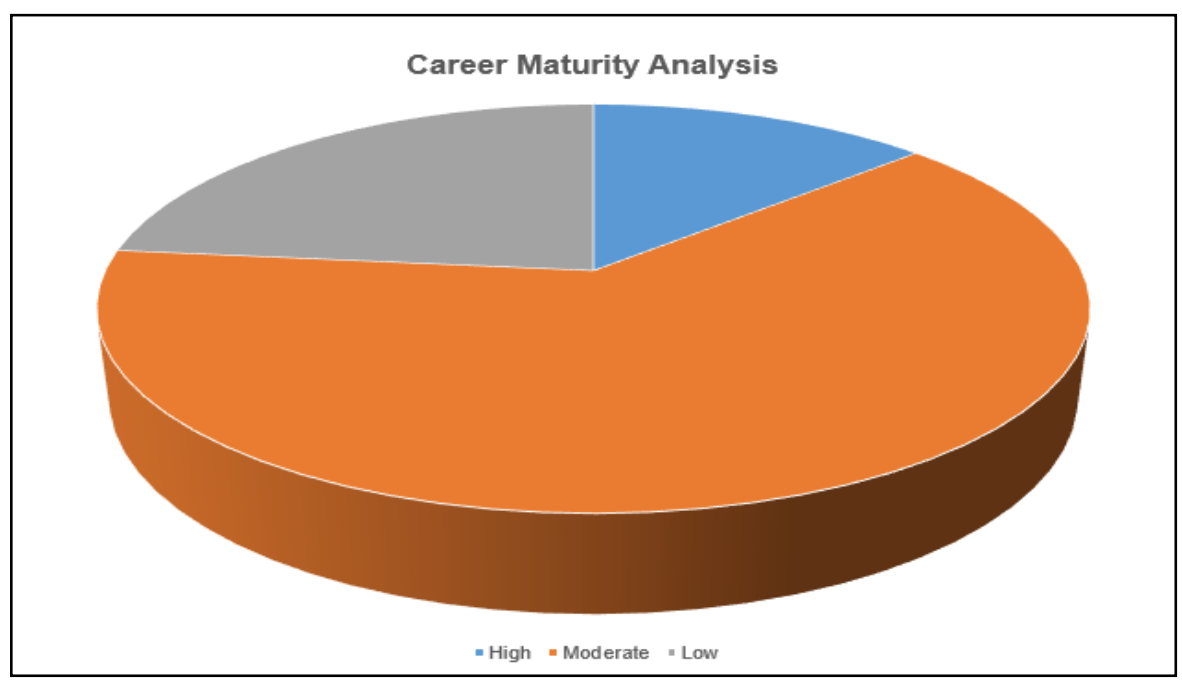

Figure 1. Career Maturity Analysis of Students with Special Needs

Interviews with guidance and counselling teachers support data on the early level of career maturity for students with special needs. The teacher said that counselling guidance learning was not given a regular schedule in class. Instead, students who want to consult about careers were carried out in the counselling room. The material for students with special needs is also no different from students in general. Therefore, teachers need media to help students learn independently according to students' level of understanding, no time limit, and can be studied at home.

\section{Product Development}

According to the Super theory, based on the results of the needs analysis, the researcher developed a career guidance product that focuses on career maturity. A proper module can be used at least passed through two stages of testing, as follow:

\section{Experts' Validation Test}

Module worthiness test is carried out by four competent experts, covering material validators by Guidance and Counseling lecturers, presentation validators by Special Education lecturers, linguistic validators by Indonesian Language and Literature lecturers, and graphics validators Educational Technology lecturers. The evaluation of the validation of the career guidance module from the material validator obtained a score of 28 . In general, material experts give comments that the module is needed to be added with goals at the beginning of each material. The linguistic validator gives a score of 18 , with comments not to use question words for non-question sentences and correcting ineffective sentences. The 
material presentation validator gets a score of 26; with comments in the evaluation section, it is necessary to explain how the counselling teacher translates the evaluation results. Finally, the graphics validator got 29 with the comments that the module is excellent and exciting. Based on the overall score given by the validators, the career guidance module being developed is in the high category level. The results of the validation test by experts were declared appropriate with revisions based on the comments of each expert.

\section{Practitioner Validation Test}

The counselling teachers carried out the practitioner validation test. The assessment results are based on 4 aspects. The material aspect obtained an average score 27, the linguistics aspect is in an average score 18, the material presentation aspect is on average score 24.5, and the graphics aspect obtained a score of 27.4. In addition to the quantitative results of the module assessment scores, there is a qualitative assessment in comments or input from expert practitioners. The comments from material experts say that overall it is pretty good; it only needs to be added with specific materials on the specific children with special needs. For linguists, the input is good, clear, easy to understand and communicative.

Meanwhile, presenting the material as a whole, the module is fascinating and easy to understand. Graphic experts say in general, the display of the module attracts the readers' interest, good illustration text that can describe the purpose of the presentation. Therefore, based on the expert practitioner's assessment, the career guidance module for students with special needs is in the high category level and is worth being used.

\section{Effectiveness test}

After the model has been developed, it has passed expert and practitioner tests and has been declared worth. Then the module is implemented for students with special needs at school. The module is implemented for students with special needs at SMK N 9 Surakarta, addressed to four students. The results of the implementation can be explained as follows. The pre-test was carried out for students with special needs to measure the students' initial career maturity level by distributing a validated career maturity scale.

Module implementation was carried out on Monday, November 16, 2020. First, the researcher gave ice breaking to students with special needs to be more enthusiastic and energetic in participating in the activities. Then, the researcher presented the material regarding the concept of career maturity, covering career planning, career exploration for students with special needs, career information, career decision making, and career orientation. The material was given by distributing career guidance modules to each student. Before starting the activity, the counselling teacher provides several directions and explanations. The researcher also provided explanations and objectives about studying career maturity materials. Students are asked to read the module by themselves, then discuss it with the researcher and the counselling teacher.

Implementation activities were continued on Tuesday-Thursday, 17-19 November 2020. This activity was carried out online by continuing the material and answering questions in the module. Activities are also carried out by discussion and question and answer session. In this activity, the researcher also conducted a post-test to students with special needs to measure career maturity after learning with the career guidance module. The posttest results will be compared to the pre-test results for further analysis. The results of students' scores are used to acknowledge the module's effectiveness in improving the career maturity of students with special needs.

The post-test was conducted on Friday, November 20, 2020, by providing a scale of career maturity to students with special needs, 27 items with validity and reliability 
tested. Below is the post-test result table of the career maturity level of students with special needs after given a career guidance module.

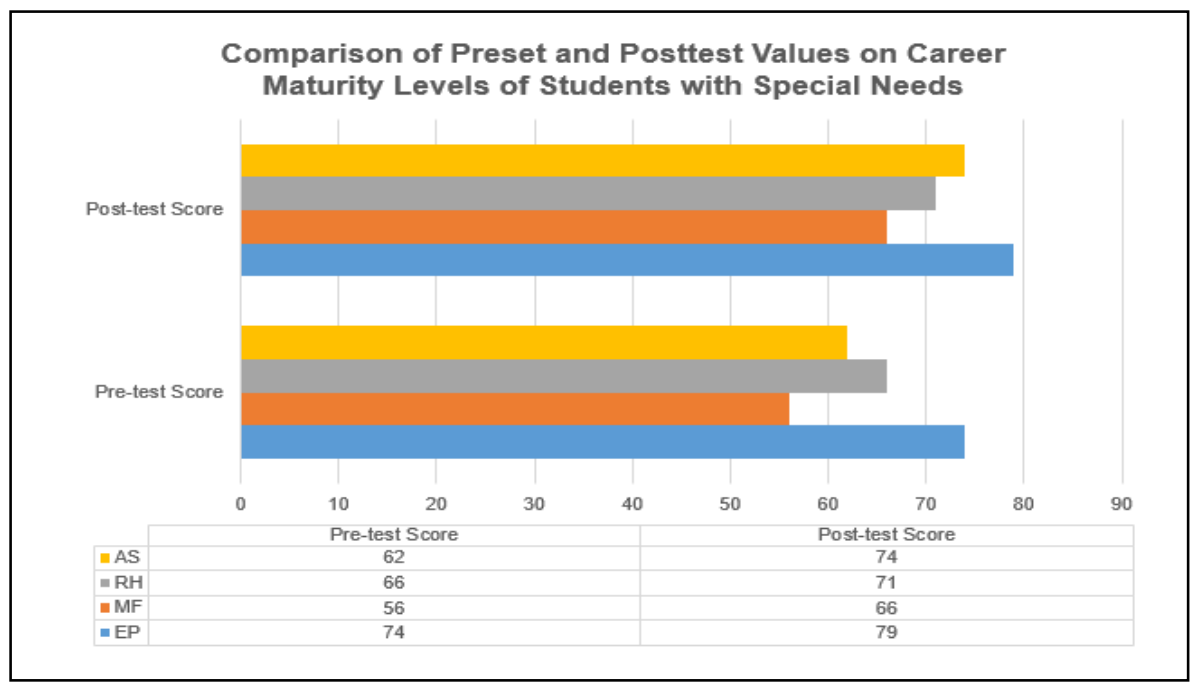

Figure 2. Comparison of Pretest and Post-test Values on Career Maturity

Levels of Students with Special Needs

Based on Figure 2, researchers conducted effectiveness tests on four students with special needs. It indicates a difference in scores before and after being given a career guidance module; in EP students, the initial score of 74 rose to 79 . MF students improved from a score of 46 to 66 . Then RH students experienced an increase of 5 scores, namely from 66 to 71. AS students also increased from an initial score of 62 to 74. Therefore, the career guidance module effectively increases students' career maturity with special needs at Surakarta Inclusion Vocational School.

\section{Discussion}

This study discusses the effectiveness of the career guidance module to improve students' career maturity with special needs at the inclusive vocational high school of Surakarta. The first finding is to measure the level of student career maturity using a scale. The results of early-career maturity before the existence of media in a career guidance module are still in the low category. The low career maturity is because students with special needs are not given career guidance learning in the classroom. Although based on interviews with guidance and counselling teachers at the inclusive vocational high school of Surakarta explained that there are no special hours to provide guidance and counselling material in class every week, the material given to students with special needs is no different with regular students. The career guidance program should have referred to the inclusive education model (Bakken, 2016; Lancaster \& Bain, 2020). Research from Heiriyah \& Haryadi (2019) and Lattu (2018) revealed that guidance and counselling teachers in inclusive schools should pay more attention to the characteristics and understand students' career interests with special needs they can become provisions for developing the potential of each student.

Based on the research findings, it can be concluded that the career maturity level of students with special needs at the inclusive vocational high school of Surakarta is still in the medium and low categories. The low level of career maturity is due to their limitations in intellectual, social, emotional and physical terms, so students with special needs need more attention to develop their career knowledge (Heiriyah \& Haryadi, 2019). Another factor that creates low career maturity of students is that most of the students with special needs do not know planning and job that they have to choose after graduates, they have difficulty making 
decisions and are not sure about their careers, causing their careers to be immature. This statement is in line with previous research showing that adolescent students have a low level of career maturity (Lau et al., 2019; Saifuddin et al., 2017). Moreover, previous research showed that in the industrial world, children with special needs are more likely to be unemployed, experiencing discrimination, being unemployed more often, and getting lower wages (Dispenza, 2019; Lombardi et al., 2018). One of the reasons for the low career maturity of students, one of which is the career guidance program that has not been appropriately implemented. Previous research by Fitriyah et al. (2018) and Novitarani \& Wahyuno (2018) career guidance services for vocational students were carried out well and could increase students' career maturity. Students in Asia benefit from career guidance through career counselling services (Lau et al., 2019). The implementation of counselling guidance for students with special needs can be done by developing teaching materials in the form of modules (Bancin et al., 2019).

The second finding is developing a career guidance module; the module has gone through several tests and is in the high category and feasible. The validation experts and practitioners provide an assessment based on Permendikbud No.8 of 2016 concerning Books used by the Education Unit, which consists of 4 assessment aspects: material aspects, linguistic aspects, material presentation aspects, and graphic aspects. These findings are in line with (Simarmata, 2019) who conducted development research in the form of a career guidance module with the results of an assessment worthy of use. The effectiveness test shows an increase in the score of career maturity before and after being given a career guidance module. This score shows that by providing a career guidance module, students will gain more knowledge to determine their career plans more thoroughly. Research conducted by (Trianasari \& Purwanta, 2019) supports that the development of an effective career information module can improve student careers.

According to Trianasari \& Purwanta (2019), selecting a module as a career guidance teaching material differs from students in general, using reading in a language that students with special needs easily understand and can be studied independently. The selection of modules as teaching materials is also based on their advantages; to improve the efficiency and effectiveness of learning in schools to achieve optimal learning goals (Hutama, 2015). Furthermore, the implementation of the career guidance module that has been given effectively improves the career maturity of students with special needs. With the career guidance module, students can plan career options, know various career options, and be more confident in choosing their career after graduation.

The third finding is the module effectiveness test, which shows the score before and after being given the career guidance module, students' career maturity with special needs increases. The effectiveness of using modules on the career is in line with Trianasari \& Purwanta (2019) research that career guidance modules can improve the career maturity of vocational students. Furthermore, previous research by Alfriansyah \& Widarto (2018), Talib et al. (2015), and Wijaya et al. (2020) stated that the use of modules is effective to improve career development for different samples. The product results in this development research have received excellent responses from experts and practitioners. This is indicated by the value that has been given, considered as high category value of the career guidance module that has been made, which contains career guidance material to improve the career maturity of students with special needs in inclusive vocational high school. Moreover, career maturity teaching materials are effective for improving the career maturity of students with special needs. 


\section{Conclusion}

The research findings show that the career guidance module for students with special needs at the Surakarta Inclusion Vocational School, which was developed, is suitable for guidance and counselling teachers and students with special needs. Judging from the research results shows that experts and practitioners provide a proper assessment of the career guidance module. Furthermore, implementing the career guidance module given to students with special needs shows career maturity after being given the effective module to increase the student's career maturity. Therefore, a career guidance module is needed to support an effective learning process for students with special needs.

\section{References}

Bakken, J. P. (2016). General and special education inclusion in an age of change: An introduction. Advances in Special Education, 31, 1-12. https://doi.org/10.1108/S0270-401320160000031001.

Bancin, I. K., Mudjiran, M., \& Rusdinal, R. (2019). Development of guidance and counseling module on self-regulation of students in social relations. Journal of Counseling and Educational Technology, 2(1), 6. https://doi.org/10.32698/0341.

Bonaccio, S. (2019). The Participation of People with Disabilities in the Workplace Across the Employment Cycle: Employer Concerns and Research Evidence.

Carter, E. W., Awsumb, J. M., Schutz, M. A., \& McMillan, E. D. (2020). Preparing Youth for the World of Work: Educator Perspectives on Pre-Employment Transition Services. Career Development and Transition for Exceptional Individuals. https://doi.org/10.1177/2165143420938663.

Chun, J., Connor, A., Kosciulek, J. F., Landon, T., \& Park, J. (2016). Career Development for Youth with Disabilities in South Korea: The Intersection of Culture, Theory, and Policy. Global Education Review, 3(3), 57-74.

Dispenza, F. (2019). Empowering the Career Development of Persons With Disabilities ( PWD). 1-16. https://doi.org/10.1177/0894845319884636.

González, M. Á. (2008). Career maturity: A priority for secondary education. Electronic Journal of Research in Educational Psychology, 6(16), 749-772. https://doi.org/10.25115/ejrep.v6i16.1301.

Heiriyah, A., \& Haryadi, R. (2019). Exploration of Career Differences in Career Interests of Students with Special Needs. KONSELI: Jurnal Bimbingan Dan Konseling (EJournal), 6(2), 141-148. https://doi.org/10.24042/kons.v6i2.5105.

Johnson, D. R., Thurlow, M. L., Wu, Y. C., LaVelle, J. M., \& Davenport, E. C. (2020). IEP/Transition Planning Participation Among Students With the Most Significant Cognitive Disabilities: Findings From NLTS 2012. Career Development and Transition for Exceptional Individuals, 43(4), 226-239. https://doi.org/10.1177/2165143420952050.

Kosine, N. R., Steger, M. F., \& Duncan, S. (2008). Purpose-Centered Career Development: A Strengths-Based Approach to Finding Meaning and Purpose in Careers. Professional School Counseling, 12(2), 2156759X0801200. https://doi.org/10.1177/2156759x0801200209.

Lancaster, J., \& Bain, A. (2020). Teacher preparation and the inclusive practice of pre-service teachers: a comparative follow-up study. International Journal of Inclusive Education, 24(12), 1311-1325. https://doi.org/10.1080/13603116.2018.1523954.

Lattu, D. (2018). Peran Guru Bimbingan dan Konseling pada Sekolah Penyelenggara Pendidikan Inklusi. Jurnal Bimbingan Dan Konseling Terapan, 2(1), 61-67. https://doi.org/10.30598/jbkt.v2i1.236. 
Lau, P. L., Chung, Y. B., \& Wang, L. (2019). Effects of a Career Exploration Intervention on Students' Career Maturity and Self-Concept. Journal of Career Development, 1-14. https://doi.org/10.1177/0894845319853385.

Liu, Y., Peng, K. Z., Mao, Y., \& Wong, C. S. (2017). Different Forms of Relationships Between Vocational Interests and Career Maturity in Chinese Context. Journal of Career Development, 44(5), 425-439. https://doi.org/10.1177/0894845316661831.

Lombardi, A. R., Dougherty, S. M., \& Monahan, J. (2018). Students With Intellectual Disabilities and Career and Technical Education Opportunities: A Systematic Literature Review. Journal of Disability Policy Studies, 29(2), 82-96. https://doi.org/10.1177/1044207318764863.

Majoko, T. (2019). Inclusion of Children With Disabilities in Physical Education in Zimbabwean Primary Schools. SAGE Open, 9(1). https://doi.org/10.1177/2158244018820387.

Munawir, M., Yusuf, A. M., Effendi, Z. M., \& Afdal, A. (2018). Internal Locus of Control and Self-Concept as Factors Affecting the Career Maturity of High School Students. International Journal of Research in Counseling and Education, 1(2), 24. https://doi.org/10.24036/0018za0002.

Novitarani, S. W., \& Wahyuno, E. (2018). Layanan Bimbingan Kematangan Karir bagi Peserta Didik Berkebutuhan Khusus di SMK Inklusi. Jurnal Ortopedagogia, 4(2), 115-119. https://doi.org/10.17977/um031v4i12018p115.

Qvortrup, A., \& Qvortrup, L. (2018). Inclusion: Dimensions of inclusion in education. International Journal of Inclusive Education, 22(7), 803-817. https://doi.org/10.1080/13603116.2017.1412506.

Risqiyain, L. H., \& Purwanta, E. (2019). Pengembangan Multimedia Interaktif Informasi Karier untuk Meningkatkan Kematangan Karier Siswa Sekolah Menengah Kejuruan. Jurnal Kajian Bimbingan Dan Konseling, 4(3), 88. https://doi.org/10.17977/um001v4i32019p088.

Riyadi, A. R. (2017). Pengembangan Alat Ukur Kematangan Karier Siswa Sekolah Menengah Atas. Jurnal Ilmiah Psikologi Terapan, 5(2), 60-79. https://doi.org/10.22219/jipt.v5i1.3837.

Saiffudin Azwar. (2012). Penyusunan Skala Psikologi. Pustaka Pelajar.

Saifuddin, A., Ruhaena, L., \& Pratisti, W. D. (2017). Meningkatkan Kematangan Karier Peserta Didik SMA dengan Pelatihan Reach Your Dreams dan Konseling Karier. Jurnal Psikologi, 44(1), 39. https://doi.org/10.22146/jpsi.17378.

Sukmadinata, N. S. (2012). Metode Penelitian Pendidikan. PT. Remaja Rosdakarya.

Talib, J. A., Salleh, A., \& Amat, S. (2015). Effect of career education module on career development of community college students. 37-55. https://doi.org/10.1007/s10775014-9279-X.

Trianasari, D., \& Purwanta, E. (2019). Developing a career information module to increase career fantasy of elementary school students. 323(ICoSSCE 2018), 25-31. https://doi.org/10.2991/icossce-icsmc-18.2019.5.

Wibowo, D. M. L. M. E., \& Tadjri, I. (2013). Pengembangan Modul Bimbingan Karir Berbasis multimedia interaktif untuk meningkatkan kematangan karir siswa. Jurnal Bimbingan Konseling, 2(1), https://journal.unnes.ac.id/sju/index.php/jubk/article/view/1230.

Wijaya, A. S., Yusuf, A. M., \& Irianto, A. (2020). A development of career guidance modules to improve youth career planning: Study at the Parupuk Tabing youth family development, Koto Tangah, Padang, West Sumatra. 464(Psshers 2019), 10-14. https://doi.org/10.2991/assehr.k.200824.003. 